\title{
Zero-Tolerance in Catalonia: Policing the Other in Public Space
}

\author{
Martin Lundsteen ${ }^{1,4}$ (D) Miquel Fernández González ${ }^{2,3}$
}

Accepted: 3 October 2020 / Published online: 18 November 2020

(c) The Author(s) 2020

\begin{abstract}
Recent studies have argued for more nuanced understandings of zero tolerance (ZT) policing, rendering it essential to analyze the significance and actual workings of the policies in practice, including the context in which they are introduced. This article aims to accomplish this through a comparison of two case studies in Catalonia: one in the neighborhood of Raval in Barcelona and one in Salt-a municipality in the comarca (or county) of Girona. We identify a transformation in the use of ZT policies in Catalonia and a contradiction between their social effects and proclaimed objectives. This article attempts to address how specific sociocultural groups gain power and privilege from these policies. The main argument is that a set of commonsensical ideas have become hegemonic, which allows and naturalizes certain sociocultural practices in urban space, while persecuting others, fundamentally pitting two categories against each other: the desired civil citizen and the undesirable and uncivil stranger.
\end{abstract}

\section{Introduction}

Researchers have been calling for a more accurate and nuanced rendering of the actual processes of policing - for an analysis that goes beyond the set of normative statements on which the zero tolerance (ZT) policies are based and for attention to the agents, discursive and relational aspects involved (e.g., Stuart 2015). Likewise, others have argued for the

Martin Lundsteen

martinlundsteen@gmail.com

Miquel Fernández González

miquel.fernandez@uab.cat

1 Research Group on Reciprocity (GER) and Observatory of the Anthropology of Urban Conflict (OACU), Centre for Criminology, University of Oxford, St Cross Road, Oxford OX1 3UL, UK

2 Research Group on Exclusion and Social Control (GRECS) of the la Universitat de Barcelona, Barcelona, Spain

3 Sociology Department, Faculty of Political Science and Sociology of the Universitat Autònoma de Barcelona, Building B2, Central Axis Avenue, Cerdanyola del Vallès, 08193 Barcelona, Spain

4 Department of Political and Social Sciences, Universitat Pompeu Fabra, Ramon Trias Fargas, 25-27, 08005 Barcelona, Spain 
need to attend to contexts in which ZT policies are implemented and recognition of how they might differ from Anglo-Saxon realities (Galdon-Clavell 2016).

The present article is based on the premise that a large part of the literature has focused mainly on: (a) the theoretical evolution of the underlying ideas of ZT (a history of the approach, so to speak); (b) abstract implementation of the ZT policies (often implying an acritical social acceptance of them); (c) limited case studies (with a primary focus on policing of specific populations, such as homeless individuals or prostitutes); and d) specific physical spaces of urban areas. Despite some interesting exceptions (some of which have been quite important for this article, such as Bannister et al. 2006; Di Ronco 2017; Duneier 1999; Fernández Bessa and Di Masso 2018; Ilan 2011), the majority of research and scholarship has paid little attention to one or more of the following: (a) how ZT policies are communicated and enter the public conscience (the fact that somebody-specific agents and the media - promotes them); (b) how they are actually incorporated or grounded and subsequently justified in practice in local politics; (c) their social effects (not only the effects on the people who are targeted by them, but also, more broadly, the collateral effects on society and other processes, such as gentrification and social inequalities); and (d) the specific setting of small towns.

Although some of the literature has addressed some of these issues, there have been few attempts to deal with them in an integrated way. In this article, we will explore the first three issues or gaps in the literature (leaving the fourth to be dealt with more thoroughly elsewhere). Taking inspiration from Di Roco (2017: 119), who contends that "[c]ontemporary cultural accounts of incivilities and their regulations should... investigate how people represent the urban spaces at the micro level of the community, the area, the district, the neighborhood and (if relevant and appropriate) even at the level of the single road or street," we engage in a comparison of data drawn from two ethnographic studies: one carried out in the neighborhood of Raval (Barcelona) and the second in the small town of Salt in the comarca (or county) of (Girona). The implicit idea is that the case studies highlight valuable features when it comes to the actual workings of the policies, the politics behind them, their symbolic aspects, inherent power struggles and, more generally, their connection to socioeconomic processes. In the end, this approach allows us to explain the establishment of a new common sense that naturalizes certain sociocultural aspects in urban space. This new kind of doxa of public behavior implies the denial of Goffmanian (1990) "civil inattention" (giving others a sense of privacy in public space), systematically pointing out and persecuting others and, ultimately, pitting two categories of populations against each other: the civic citizen (desired) and the strange and uncivil other (undesirable).

The ethnographic data on which this article is based are drawn from fieldwork conducted for two separate PhDs - one undertaken in Salt (a small town located in the Girona region) between 2011 and 2014 (see Lundsteen 2015) and the other in Raval (Barcelona) between 2009 and 2012 (see Fernández González 2014). More specifically, the methods applied included observation of ordinary life on the streets and formal and informal interviews. Both of us conducted semi-structured interviews with public administrators and police officers. Both of us found observation and informal conversations with sex workers, drug dealers and residents to be more fruitful than interviews. These data have been analyzed with qualitative data analysis software.

The structure of the article is as follows. After a review of the literature and how it relates to specific geographic and historical contexts (thereby addressing aspects of (a) and (b) above), the part entitled "The Micro-politics of Civility in Catalonia" addresses the implementation of ZT policing (relating to aspects of (a), (b) and (c))). The last part, "The Effects of the Culturization of Civility on Social Relations in the Neighborhood," looks at 
the social effects of ZT policies in Raval and Salt, respectively, and their relation to different interests and sociocultural norms (speaking to (c) and (d)).

\section{From “Authoritarian Populism" of Thatcherism to Quality-of-Life, Zero Tolerance and Civility}

It was in the footsteps of what Hall (1979) dubbed "authoritarian populism"- a mix of the fundamentals of the abstract economic philosophies of Austrian liberalism and "popular sentiments regarding "nation, family, duty, authority, standards, self-reliance"" (Haider 2018: 94) — that the now famous doctrines of ZT would emerge in New York City in 1998 from the office of then-mayor Rudolph Giuliani. The new strategies were categorized under the rubric of so-called "quality-of-life" policing (Johnson et al. 2010). Later, similar practices were promoted by New Labour in many council estates of London through the Crime and Order Act 1998 (Guillen 2009).

The ZT approach relies heavily on the "broken windows" perspective, made famous by Wilson and Kelling (1982), which suggests that "disorder" (in urban neighborhoods), such as graffiti and vandalism, as well as petty crime, if left unchecked, sends a message that a community does not care, which can lead to more serious crime. The argument is that to address crime, one must first confront disorder and uncivil behavior.

The "broken windows" perspective gave rise to the notion of the police as "guardians of order," rather than merely ex post responders, who become involved only after a crime has been committed. De Giorgi (2000:158) described how this change impacted the way police deal with minor crimes:

Substantially this means that the police must repress those behaviors which, although they do not specifically constitute a crime, are deemed unpleasant, annoying, and which present a degrading image of the city; urban graffiti, aggressive begging, the perseverance of the window washers working at the traffic lights, street prostitution, public drinking, the visibility of the homeless, and any similar situation.

Accordingly, focus shifted from the possible causes of deviant behavior to its public expression, which constituted a possible threat to the reigning norms and values of the communities.

As noted above, this framework arose first in New York City, with repressive policies directed toward misdemeanors that jeopardized the "quality-of-life" of the inner cities in the 1990s (Onishi 1994). The idea of selective intolerance regarding public behavior would be exported quickly to the United Kingdom and the rest of Europe (Wacquant 2009)—first through media campaigns and later via administrative sanctions.

These policy innovations would progressively catch on in the habitus of the newly emerging middle-classes of the recently sanitized central districts of New York City and London-inhabitants who would quickly subscribe to the new doxa of public behavior. The adoption of new mores with respect to class, culture and hygiene in previously "uncivil" spaces forced them to adopt a role much more akin to the colonizer than the citizen (Atkinson and Bridge 2005).

In fact, the transition to "quality-of-life" policing and ZT strategies of urban control in New York City quickly became paradigmatic. In essence, they constituted a new wave of regulations of behavior in public space. The aim was not to fight the origin of the discontent (economic crisis and unemployment) but the crude manifestation of this in the central 
streets of the burgeoning "global" or "creative" cities. At the same time, the hope was to make these central but impoverished neighborhoods more attractive places for intellectual and artistic Bohemians-pioneers in the well-known processes of gentrification; the hope was also that a new urban logic of the "institutional production of disorder" (Fernández González 2014) would emerge-one that would encourage a moral panic (Cohen 2002) among these new neighbors and, thereby, legitimize the hostility they directed toward disorder and the "traditional neighbors" (still) dwelling in these coveted central spaces. (Fernández González 2016).

The doctrines of ZT, which flourished in the 1990s, have, since then, expanded to other parts of the world, although mainly to countries in the Global North (Wacquant 2009; Wacquant et al. 2014). As a result of these measures, "anti-social behavior" has multiplied in annual statistics at the expense of "crimes and misdemeanors" (Mooney and Young 2016). Accordingly, certain "disorderly" behavior in public space must now be controlled-either through prevention or forceful dissuasion that such behavior is inappropriate (Greene 2014). In fact, despite different sociocultural histories in different geographic locations, ZT policing (whether in New York City, London or Barcelona) shares many common characteristics, such as the replacement of informal social control with more bureaucratic governmental and police control, and the final aim of strengthening social cohesion in highly dense and diverse neighborhoods through the repression of public behavior deemed inappropriate (Bannister and Keans 2013; de Giorgi 2000; Merrifield 2000; Bass 2001; Millie 2009; Mooney and Young 2016). What "inappropriate" means is less clear, however, and becomes fundamentally a moral and highly contested sociocultural question. In fact, one might ask: whose quality-of-life are we talking about?

\section{Repressive Measures in Catalan Public Space: Political Campaigns, Culture and Class}

Over time, the original premises of ZT were adapted to the realities of different local contexts. In some places, where there was little major crime, curbing disorderly behavior and changing attitudes became the end, rather than the means (Millie 2009; Mooney and Young 2016). Indeed, thanks to self-fulfilling prophecies and intense media campaigns, "incivility" became one of the more pressing issues for politicians and society at large. Experts and academics claimed links between civility and living together, accusing the "uncivil" not of being criminal, but of constituting a menace to "peaceful coexistence" and democracy (Howell 2016; Subirats 2006). Essentially, ZT policing began to function in such a way as to clear the more upscale consumer scenes and public spaces of the "annoying" poor, who were considered undesirable, unnecessary (economically speaking) and eyesores. The end result was a "decline in crime and the rise of anti-social behavior" (Mooney and Young 2016: 397).

As Smith (2001: 69) observes, "to varying degrees, Dublin, Sao Paulo, Barcelona, Bremen, Oslo, Vienna, and Stockholm have [all] integrated ZT approaches to their policing strategies" (Smith 2001: 69). In Catalonia, the ZT approach was introduced under the name of "Ordenances de Civisme" (Civility Ordinances or "CO"). In our case studies in Barcelona and Salt, the end of "the uncivil" would become the beginning of selective intolerance. "Brutal pressure from the media," as Albert Villagrassa, a member of the People's Party (Partido Popular) and a councilor on the Barcelona City Council would describe it (Oriola Folch 2007) was initiated by the Catalan and Barcelona-based conservative newspaper, $L a$ Vanguardia $(L V)$, against the progressive city council; $L V$ accused the council of 
abandoning and degrading the streets of Ciutat Vella (a district of Barcelona) and, to do that, $L V$ used a new sense of the epithet "incivility": from then on, incivility and insecurity became complementary concepts (Zuloaga 2014; García and Ávila 2016).

In fact, the first uses of the civility paradigm were driven by the political and economic restructuring programs initiated in the last decade of the twentieth century; they would establish urban designs built with the goal of a more restrictive control of public space and the production of surplus value (Sassen 1991; Wacquant 2009). While these approaches tended to be the focus of American cities, more recent publications on civility rules have also been examined the context of Barcelona (e.g., Galdón-Clavell 2016).

Relying on several authors (e.g., Hill 2005; Ismaili 2006)—and undertaking an archival and newspaper analysis of the creation of the CO-Galdón-Clavell (2016) identifies certain political tensions between conservative and progressive parties, which led to the introduction of the "Ordenança sobre l'ús les vies i els espais públics de 27 de novembre de 1998" (Ordinance on the Use of the Street and Public Space in 1998) - the precursor to the actual CO. In Barcelona, the more progressive political parties offered a rhetoric more in line with the voters, placing emphasis on education and ethics for the citizenry rather than repression, as the conservative parties had done traditionally. To comprehend the success of this framing, however, the role of the media must be examined.

The media and $L V$, in particular - the largest and most influential newspaper in Barcelona ${ }^{1}$ - exerted pressure on politicians to categorize certain public behaviors as "disorderly" and "inappropriate." 2 The stated reason to curb the "wave of incivility" was that, otherwise, such behavior would "ruin the future of our cities"- a position underscored by the most influential politicians of the Spanish state (Roca i Junyent 2003). ${ }^{3}$

An inseparable link between disorder, filth and incivility, on the one hand, and insecurity, on the other, was becoming accepted as natural, creating a causal and an inevitable chain reaction. The sensation of insecurity impregnating Barcelona at that time, indeed, constituted a phantasmagoria, which was easy to exploit for political purposes. As the precariousness of housing and work increased, and as an ever-growing number of people felt defenseless and hopeless, interested parties' misrepresentations associated the sensation of insecurity exclusively with "begging, prostitution, street vending, peeing and spitting in public roads, bunking off school, window washers and graffiti artists" (Ruíz Simón 2005) - despite the fact that these occupations are, in general, quintessential expressions of unequal access to cultural, economic or social resources. These vulgar social facts had just "wandered around each on their own, without any concept that gave them a common shelter" (Ruíz Simón 2005).

\footnotetext{
1 The difference, in terms of circulation, between $L V$ and the second largest newspaper was around 20,000 copies per day in 2004 (Ajuntament de Barcelona 2006).

2 According to the analysis of the news from 2003 to 2005 (Fernández González 2010) and the declaration made by Maite Fandos, councilor of Convergencia y Unión (CiU), the Catalan conservative party, on the Barcelona City Council, "the newspaper La Vanguardia has done a favor to the citizens, capturing a theme that was worrying people [incivility] and putting it on the front page" (Oriola Folch 2007). During this period, 700 news items - approximately five per week - appeared on the topic.

3 The author, a former Member of Parliament for the CiU, is also a distinguished member of the executive boards of some of the main companies in the IBEX 35 (the main Spanish stock index that includes the main Spanish multinationals, such as Iberdrola, Inditex, Movistar and Repsol).
} 
The strategic introduction of a link between insecurity and incivility in the political debate gave way to the appearance of "a new problem, a new anxiety" (Galdon-Clavell 2016: 10) and created the need to curb the "sensation of insecurity" (Zuloaga 2014) through the containment of micro-disorders. ${ }^{4}$ As in other European countries (Bannister et al. 2006), progressive parties accepted the social problem of "disorderly" behavior in public, as it had been constructed by the conservative sector of society, but they offered what would later be known as a citizenist rhetoric $^{5}$ (Alain 2001), thus displacing the punitive mode of the conservatives.

Consequently, the shared assumptions about what the city and public space ought to be like led to most of the political forces, both progressive and conservative, to agree that the political and legal framework had, until then, been "too permissive" (Muñoz 2005). Simultaneously, migrants were being singled out as the most uncivil people, causing terrible consequences for those migrants who had, in fact, been sanctioned for uncivil behavior: They would either have the renewal of their residence and work permit withdrawn or their registration of residency in the town rejected for infractions of the associated social laws (EFE Agency 2005). Whatever the causes, once the new problem of "incivility" had been introduced into the municipal agenda, the "most appropriate solutions" were adopted vis-àvis electoral perspectives and media pressure.

\section{Community Policing and Populist Punitiveness}

Some authors (e.g., Giroux 2003; Lum 2009), writing on the topic of community policing, agree that the shift toward more restrictive uses of public space has occurred in areas where democracy is less established. This approach, referred to as "populist punitiveness" (Bottoms 1995), involves a combination of media messages that increase feelings of insecurity and, at the same time, demand immediate and simple political responses (Campbell 2015). This approach favors the use of public places as little more than spaces of transition between home, work, and shopping establishments. Those who use public spaces for fun, for work, or for other activities and "practices" (Lefebvre 1991) are labeled as "antisocial," "uncivil," or "untrustworthy" (Bannister and Kearns 2013; Millie 2009; Mooney and Young 2016; Stuart 2015).

These theoretical discussions point in different yet complementary directions. They offer an explanation for the transformation of public space as the consequence of a cultural hegemony of the middle-classes. The gaze that these middle-classes cast is produced through "public opinion," as seen in the years prior to the approval of the CO in Catalonia. In particular, a series of articles, books, conferences and speeches, to which several influential academics contributed, legitimized and rationalized the new culture of control and repression in Catalonia. These acts and publications promoted a change in the dominant ideas of the political field, imported directly from the sociological doxa of the moment

\footnotetext{
4 "Micro-disorders," according to civility regulations, include not cleaning up after one's dog; spray-painting public walls; skating; drinking, eating, washing or sleeping in the street; distributing or hanging political propaganda on public walls during a non-election cycle, and playing music or performing any stage act without the corresponding authorization.

5 As Alain (2001:1) describes, by citizenist, "we understand in principle an ideology whose main features are: The belief that democracy is capable of opposing capitalism. The project to strengthen the State (or States) to implement this policy. The express purpose of citizenship is to humanize capitalism, make it more just, provide it in some way, a supplement of soul."
} 
(Camps and Giner 1998; Cardús 2003, 2006; Debray 2000; Subirats 2006). This kind of offensive on the part of the municipal intelligentsia reached its paroxysm when one of the preeminent sociologists in this debate, Salvador Cardús, defined the uncivil as "socially unbalanced, no matter how good a person he might be" (Escur 2003).

On the other hand, as several authors point out, the normative imposition of a way of conceiving and being in public space can have the opposite effect and, instead of favoring social cohesion and living together, can lead to estrangement and social polarization, urban tension and malaise (Babe Howell 2016; Mooney and Young 2016). Such an approach to public space can encourage racism, thinly veiled as a concern for "civility" or "disorderphobia," and can treat different attitudes toward and use of public space as a threat to an idealized peaceful coexistence (Bass 2001; Curtis and Cuny 2012; Bannister and Kearns 2013). Moreover, as some authors have noted (see, e.g., Bannister et al. 2006; Ilan 2011), a notable class bias is reflected in these ideas, whereby the interests of the dominant social groups are privileged over more vulnerable populations. What had, until the enactment of the policies, been considered a precarious means of subsistence, would, from then on, be considered an illegal use of public space (OSPDH 2009). The mechanisms involved converting what was essentially selective intolerance into protection of the traditional values of the community from the influence of strangers/foreigners and other "unassimilated" individuals (Kefalas 2003). It is, in this sense, that civility policies seem to promote intolerance toward other forms of being and ways of using public space.

It is worth noting that, in the places we studied, "incivility" is strongly culturalized and culturalizing - and this was already present when the $\mathrm{CO}$ was first introduced. The fundamental premise is that public space has been altered. According to the legislators, the "increase in uncivil behavior[,] which endangers the convivencia," "increase in geographical mobility and economic globalization[,] which tends to mix peoples from different cultures" (multi-culturalism or super-diversity, and the "problems of migration"), as well as an individualized and consumerist "youth." With respect to the latter, the problem "does not come from outside."

[Rather, it is] related to people from the place. A loss of proper cultural norms has taken place, which leads to a social situation of anomie, of loss of meaning, in which the individuals lacks the knowledge regarding the orientation of their behavior, while the boundaries of this has not been well defined socially (Comissió de Presidència 2005: 7).

The Durkheimian or Mertonian influence of this position is obvious, as is the influence of the ideas of Putnam (2000) on social capital and community. In fact, the CO reflects the idea of a decline in social capital, resulting from the breakdown and erosion of many major social institutions that might have offered sources of collective identity and solidarity.

In the case that it is effective in modifying behavior on the street, the institutionalization of civility implies a negotiation of the uses of public space. In this sense, it is paradigmatic of what Habermas, following Schütz (1953), interprets as an attempt on the part of the

\footnotetext{
${ }^{6}$ Convivencia is a Spanish and Catalan term which was originally employed by the philologist Ramón Menéndez Pidal to describe the competition and coexistence of various phonetic forms of early Romance languages on the Iberian Peninsula. It was later developed by one of his disciples, Américo Castro, to refer to the ideally peaceful interaction and cohabitation of medieval Christians, Jews and Muslims in the $A l$ Andalus. Currently, however, the notion implies both an initial difference in culture, habits, language, religion, and so on, and a mutual acceptance among the different communities. It is often used to signify a situation that transcends mere "coexistence"-one of "live and let live."
} 
system to colonize the living environment (Lebenswelt). Specific cultural forms- the ones deemed "civil" - are imposed by institutions via municipal regulations, promoted by the political and academic doxa, and enforced by the police, while others are considered inadequate, unacceptable and counterproductive (Benz 2014).

\section{The Micro-politics of Civility in Catalonia}

The arrival of ZT to Catalan society, mostly through political circles and the media, accompanied the emergence of a new idiom, one which could easily be passed off as postracial and reform-oriented: citizenist (Alain 2001). The new term gave the impression of a social project which, in many ways, had become an alternative to what had been perceived as a more brutal law-and-order approach in a time of triumphant capitalism and economic boom. It persuaded many middle-class people, however, in the end, it was yet another social reform project aimed at governing the poor and miserable in space (Lundsteen 2015). In fact, the new idiom was introduced alongside other urban reform projects.

For instance, in Barcelona, the improvements that were expected in the Robadors area with respect to public space or the quality of housing would have entailed "an ever more normalized circulation of the residents in the district and, therefore, logically a renewal of the people" (Abella 2004: 94-96) was expected. This statement, made by the director of the public-private company in charge of the renovation, was accompanied by an invitation not to fear "the important concentration of Pakistani and Maghrebi migration in the area [because] this, apparently constant and a bit disturbing, presence will fade away little by little" (Abella 2004: 94-96). Our fieldwork shows how these expectations in Barcelona and, similarly, in Salt, were not fulfilled-a fact that would justify subsequent regulations of control over the public space with the aim of modifying public behavior and adjusting to a norm without conflict. Absent this, the "Othered community," so to speak, would feel compelled to move out and give way to families "in better conditions... with a well-organized family structure," as Emma, an employee at the Institut d'Estudis Catalans (an important cultural non-profit organization in the neighborhood) stated in March 2011.

In November 2010, a small group of neighbors in the Raval neighborhood of Barcelona gathered to talk about the difficulties they faced and the future of the neighborhood. Approximately twenty-five people were present at the meeting, called Raval per viure ("Raval to live in"). Some presented themselves as new to the neighborhood, while others referred to themselves as former local activists. During the meeting, a specific word was used time and again to explain all the problems in the neighborhood: incivismo-which means "incivility." But more importantly, this conceptualization implied an adopted pose of political correctness which became apparent when, at one point in the meeting, one of the speakers was criticized for using the Spanish term for Moor-moro (see Lundsteen 2018 for a more thorough discussion of this term). When one of the participants said, "No, we are not talking about moros...we are talking about drug dealers," another replied, "Yes, drug dealers, prostitutes, squatters...we don't care where they come from, what bothers us is that they are uncivil." Later, while in a more relaxed atmosphere, one of them recognized that the only solution to incivility in Raval, in general, would be the destruction of the oldest and most abandoned-looking buildings where most of the low-income residents lived, as well as stricter immigration and criminal codes.

Similarly, according to one of the police officers (Mossos d'Esquadra) working in the district, whom we interviewed in February 2011, "the solution to the problem of incivility 
in Raval" is to "toughen the Criminal Act, the Alien Act, and, if this turns out insufficient, demolish the row of buildings with odd numbers, in the study street, the ones that are still standing." In his opinion, Spain had an excessive rights-based justice system, and the local civility ordinances, which, the Guardia Urbana were responsible for enforcing, were ineffective when facing the kind of crime perpetrated "in those streets."

When comparing Raval and Salt, we see that the immediate effect of the regulations, and the preceding discourse in which they are framed, has been to facilitate a unified and homogenous response to the perceived conflict and disorder taking place in public space. This partly explains its social and symbolic efficacy: the civility paradigm turns into a policing instrument as well as a political and media discursive framework, which urges condemnation and groups together all kinds of local and global imbalances. The civility paradigm renders a vision of the world, which is much more politically correct because, officially, the policy makes no explicit distinction between nationals and foreigners, but condemns people's "lack of integration" or "low cultural level." This prevents them from going unnoticed and from causing trouble, because, as Emma says "the environment, the atmosphere, in general, is very unpleasant: the filth, people... a lot of junkies..., the methadone and all that. As workers, we're all always on the lookout, to see what... where they come from... There's a very bad environment!" In essence, it is an egalitarian viewpoint which, however, conceals the existing class, ethnic, and gender stratification.

The success of the incivility paradigm in the eyes of some of the inhabitants of these "problematic urban centers" was immediate. From the very outset of the application of the $\mathrm{CO}$, the better-off residents, the majority of whom were Spanish nationals, were offered a blanket concept with which to rant about the Others - the ones who did not adjust to the purported universal ethic and aesthetic. From this moment onwards, any urban pedestrian could be accused of being uncivil, simply because he was in the street-in a place which, as if by the most radically exotic and threatening analogy, was likened to "Karachi" on national television (TV3 2010).

\section{The Effects of the Culturalization of Civility on Social Relations in the Neighborhood}

A lot of literature has debunked and denounced the ZT approach and all its corollary politics, without focusing on its concrete social effects and everyday functioning (for some compelling exceptions, see Bannister et al. 2006; Fernández Bessa and Di Masso 2018; García and Ávila 2016; Ilan 2011; Di Ronco 2017). Our ethnographic research shows how some residents promote a vision of how people should behave in public space which confers on them more legitimacy in the neighborhood in both material and symbolic terms (for a similar phenomenon in Dublin, see Ilan 2011). As will be clear, by mobilizing their cultural, political and symbolic capital, these residents with more cultural and social capitalthe middle-class-(re)produce the existing unequal power relations through a symbolic reordering of the neighborhood in social and urban terms via the (in)civility paradigm. In fact, as Bannister and colleagues (2006) argue, the proclaimed aims of improving the social relations in the neighborhood, convivencia, and living together, are contradicted in practice. The policies implemented generally hinder a well-functioning social praxis; instead, they make the residents more vulnerable, (re)produce social inequality and facilitate the ongoing processes of gentrification.

The lack of neighborly relations between the new arrivals and long-time residents is often explained by a discourse of "cultural incompatibility." As Asunción, interviewed in November 2011, tried to make clear, "it's complicated to have any kind of relation to the 
kind of people who live in Robadors Street because they are very deprived." The lumping together of epithets, such as "lower culture," "migrant," and "uncivil attitudes," as Nestor and Asunción did in an interview that we conducted with them in November 2011, creates a common discourse among new neighbors or visitors that justifies the lack of comprehension and sense of security that they feel among people and practices which are associated with cultural "Otherness" or "under-development."

Even so, the new neighbors seem to have the support of the municipal authorities to counteract these apparently discomforting uses of the streets through the organization of festivities and fairs. These are, therefore, activities in what is called "public space," but which, at the same time, has become privatized-promoted by the public institutions so that the streets are used in such a way that benefits only some of the shopkeepers. At the same time, the new repressive atmosphere imposed by the deployment of regulations means that a large number of individuals (e.g., prostitutes, street vendors, dodgy-looking people, pickpockets and, in general, people who try to make a living or who attempt to enjoy their leisure time in the street) live under constant suspicion and the threat of violating the $\mathrm{CO}$.

This strategy, however, requires that an increased number of effective "new neighbors" "take the street," as Néstor stated:

The City Council tells us to "take the street," but how do you take this street? Festivities in the street...but these people they don't know... Do you know what the real problem is? The cultural level of the people living here is so low, these people are like the Spaniards in the $40 \mathrm{~s}$. For them it's natural to spit in the street. Stay here and observe for $10 \mathrm{~min}$ or so and you'll see that this is the only street that is cleaned three or four times a day and yet it's always filthy...but we don't surpass the percentage, we're too few.

It goes without saying that, when an abstraction, such as civility, becomes culturalized, it can morph into nationalism - an exclusion that adds both pride and hate to the technocratic criteria. Affirming that "civility is patriotism" (Cardús 2006: 102) requires nonnationals, like immigrants, to show their appreciation of the patria by becoming civic role models, calm and immaculate, while the nationals who do not behave adequately become Othered, considered "foreign," and subsequently treated as second-class citizens-a manifestation of an incommensurable radical alterity.

The ultimate effect of "culturalizing" civility is that it allows for concealing exclusionary strategies, stigmatization, and even hostility. For instance, instead of talking about inferior races, which might bring about scorn or reprimand, one can talk about "cultural differences" when one wants to justify repressing people who use the public space more openly or intensely. In this way, one can impute a lack of education to these people without using politically incorrect language. This formulation is, in fact, double-edged: it suggests that foreigners and migrants lack cultural capital and, at the same time, that they come from places which are "culturally underdeveloped."

The end result, we contend, is that the actual social effects or consequences of the ZT policies extend further than the stated objectives. Indeed, the measures might also be considered revanchist policies (Smith 1996) aiming to reduce or avoid any kind of social conflict which could, and normally would, take place in public space through the expulsion of actors deemed to be a "menace," an "invader," a "transgressor" or simply "troublesome"- with the ultimate goal of exclusive access for the "nationals" and middle-classes. We see how this works by observing two important and polemic measures employed in 
Salt to counter "incivility": the prohibition of satellite dishes and the removal of drinking fountains.

In 2003, a local civility ordinance was been adopted in Salt (see Lundsteen 2015, 2020). It was not until 2007, however, that the ordinance began to be enforced. Among the provisions was an extension to the already existing prohibition (established in 2004) of installing satellite dishes on the facades of buildings and leaving rubbish and trash on balconies under penalty of a fine. Although the prohibition of satellite dishes on the buildings was, according to the former mayor, a policy to promote a certain aesthetic and increase security, other reasons had clearly influenced this because the city council had promised to act in response to complaints about the presence of dishes on some balconies without any reference to aesthetics or concerns about security. In fact, the former mayor, Iolanda Pineda, from the Catalan Social-Democratic Party (PSC), acknowledged this when we interviewed her in June 2012, stating that some people had complained to her by saying "before this was a very nice neighborhood and now look at it, look at the kind of deprivation we suffer, look at the balconies, look...."

In 2011, the city council decided to close the drinking fountains in the city, citing similar concerns about aesthetics and security. Once again, however, these were fused with the idea of the "uncivil" user-the cultural Other who did not know how to behave correctly or possess the cultural tools to use the fountains responsibly. The fact is that the city council decided to act in response to the complaints of some of the neighborhood residents and close the fountains, instead of using other more pedagogical tools, such as a public campaign, to solve the conflict between the neighbors. In this way, the policy had the effect of criminalizing the poor without solving the underlying problems of the conflict, which may have included access to employment, housing or even drinking water.

In effect, the city council's message seemed to be that the problem is one of uncivil behavior stemming from cultural differences. The creation of a perceived culture clash gives clear examples of how political doxa works. Concern regarding the "incivility of the migrants" is put forth as a problem which must be solved-not a phenomenon to be understood in order to maintain the social contract and ensure human rights.

Another example from Salt further demonstrates this point. In 2011, the local government-in this case, the conservative Catalanist party, Convergence and Union, and two defectors from the right-wing Platform for Catalonia-introduced an innovative program called Passadissos nets, passadissos segurs (which translates as "clean halls, secure halls"). Imported directly from New York City, ${ }^{7}$ the program permitted the police to patrol with a canine unit in the neighboring communities who had signed petition (often limited to the homeowners or landlords).

The program has had, in our view, a double objective: (1) to create a sense of security through police presence; and (2) to symbolically reorder urban space and, with it, social relations. The program was presented as a plan to curb uncivil attitudes and behavior, although other objectives (such as "harmony" and "to gain familiarity with the situations of the various communities" and "to act as a deterrent to all those people who want to complicate life in a specific community," as the then mayor stated) were also apparent. According to the city council, they wanted to respond to the real problems of the neighborhood communities, defined as "neighbors who illegally tap into utility lines to obtain electricity, people who urinate in the halls or problems of illegal occupation" (Diari de Girona 2012).

\footnotetext{
7 The equivalent is the controversial Clean Halls program, ruled unconstitutional by a federal judge in New York (see http://blackandbrownnews.com/nypd-clean-halls-ruled-unconstitutional/).
} 
Moreover, in an interview in July 2012, the then-councilor in charge of Housing and Community, Glòria Pàmies (CiU), stated that the program would deal with other problems, such as drug possession and a "problematic" appropriation of public space by migrants:

In the central neighborhood there's an $80 \%$ rate of immigration...they have other habits... and at night they used to group together in front of the entrance to the buildings, and this way sometimes they make it difficult to enter, and, secondly, this... scheming that might take place obviously creates insecurity.

As one of us has described elsewhere (Lundsteen 2015), the program is similar to other public police interventions, such as raids or frisking, in its attempts to order social space: the interventions criminalize the policed subjects and establish boundaries of belonging in space (see Duneier 1999; Fernández Bessa and Di Masso 2018; Ilan 2011, for similar findings). Although, in general, these kinds of measures might even have had positive effects for some of the neighbors or for people who frequent the areas where such policies are in effect, the fact is that yet, again, another large proportion of people living or simply hanging around have had a completely opposite experience - that of not feeling welcome.

These examples serve to demonstrate how some measures or specific interventionsand especially the theatrics that they involve-influence the way people perceive and live together in these spaces, as well as the definition of the groups that conform to the social fabric of the neighborhoods: the policies separate those who have a right to be in the space from those who do not. The measures are, in their essence, symbolic policies, the principal aim of which is to show that politicians have listened to their constituents and that something is being done to improve the perceived state of the neighborhood. Particularly, they act through a symbolic reordering of social reality and space, and yet they have very manifest material consequences for those targeted or affected by (even if unintentionally) the measures.

In the end, the efficacy and popularity of these kinds of reactionary punitive measures stem from their capacity to redirect or displace any potential social conflict by giving them concrete form, while attempting to offer a solution. We observed how the canine patrol, a quintessential part of the Clean and Clear Halls program, produces the perception that the space is ordered and calm, clearing the area of all that is undesirable, including Othered individuals. And we saw how more than a few people had the experience that all the "foreigners" left the space when the dog patrol came through, thus implying that they were shady, although that was not actually the case.

\section{Conclusion}

As this article has attempted to demonstrate, the imposition of a normalized set of ethics and aesthetics, articulated in the ZT policy framework, is problematic when implemented in a public space that is part of a diverse but unequal society. We find at least two contradictions. One of these is of a moral character: ZT policies attempt to enforce a constructed normalcy which is not achievable by everyone. Another contradiction is of a logical character: conceptualizing civility as a framework for resocializing or teaching Others means disregarding the plurality of world views, tensions and conflicts which are inherent to urban space (see also Bannister et al. 2006). To pretend to pacify the effervescent characteristic of urban space through repression might encourage everyday strategies of resistance in the form of disorderly behavior, which is what the policies are meant to combat. 
This article has also endeavored to show how, although ZT policies can operate at a symbolical level, they often have a clear material effect on certain groups of people. For instance, in Spain, those who are not Spanish nationals - and whose origins are from outside the EU-are subject to evaluations of their social integration, while Spanish and EU citizens are not. Unlike Spanish and EU citizens, these non-EU immigrants can, in fact, have the renewal of their permits rejected and can be deported due to uncivil behavior. And even though they might eventually obtain Spanish citizenship, which can also be subject to revision, in the eyes of many Spaniards, this might have no effect whatsoever; Spanish citizens continue to see them as foreigners, meaning that in the end, they are in the position to articulate the authenticity of non-EU immigrants' nationality.

Moreover, the values implicit to civility, and sanctioned through the civility ordinances, are presented as something socioculturally neutral and universal. As we have argued here, however, what is, in practice, considered "civil" or "uncivil" is informed by hegemonic sociocultural norms (see also Bannister et al. 2006). That which is considered "civil" or "uncivil" is also a product of historical-geographical processes particular to each place and interrelated with changing political-economic systems. Consequently, in the resulting sociocultural fields, not everybody is equal, and by employing this kind of discourse or symbolic ordering of space, these unequal positions are reaffirmed and, at the same time, endowed with a sense of normalcy that should not be questioned.

Finally, this article has sought to reveal a process of institutionalization of a set of commonsensical ideas regarding what kind of behavior is appropriate in public space-a new doxa that redirects social conflicts originating in social inequalities, by concealing them as simple "behavioral problems." The consequence of this psychologization and the culturalization of the social conflicts is utterly perverse because it implies the naturalization of social divisions, based in the discourse of "cultural differentialism" (Taguieff 1988) and, therefore, entrenches already existing social inequalities.

What remains for further study is how and to what extent the decreasing budget of the city councils have influenced these kinds of "fast-food policies," which are cost effective and symbolically powerful (see Lundsteen 2020). In the end, governmental administrations have fewer resources to cope with social problems that often stem from economic redistribution, poverty and social discontent. Faced with this situation, governments may enact the type of publicly visible measures discussed here, which favor only those who are considered "morally reliable." Only those who comply with the hegemonic sociocultural normsthe unofficial rules of behavior in space - can be considered deserving; at the same time, such policies ensure that those who are being targeted are, indeed, also perceived as guilty. It becomes a vicious cycle.

Funding Funding was provided by the Spanish Ministerio de Educación, Cultura y Deporte (Grant FPU).

\section{Compliance with ethical standards}

Conflict of interest The authors acknowledge no potential conflict of interest.

Open Access This article is licensed under a Creative Commons Attribution 4.0 International License, which permits use, sharing, adaptation, distribution and reproduction in any medium or format, as long as you give appropriate credit to the original author(s) and the source, provide a link to the Creative Commons licence, and indicate if changes were made. The images or other third party material in this article are included in the article's Creative Commons licence, unless indicated otherwise in a credit line to the material. If material is not included in the article's Creative Commons licence and your intended use is not 
permitted by statutory regulation or exceeds the permitted use, you will need to obtain permission directly from the copyright holder. To view a copy of this licence, visit http://creativecommons.org/licenses/by/4.0/.

\section{References}

Abella, M. (2004). Ciutat Vella: El Centre Històric Reviscolat. Barcelona: Aula Barcelona.

Ajuntament de Barcelona. (2006). Anuari 2006. Estadística i Difusió de Dades. Retrieved September 29, 2020, from https://www.bcn.cat/estadistica/catala/dades/anuaris/anuari06/cap06/C0615010.htm.

Alain, C. (2001). L'impasse citoyenniste: contribution à une critique du citoyennisme. Paris: Le Trou dans le mur.

Atkinson, R., \& Bridge, G. (2005). Gentrification in a global context: the new urban colonialism. London: Routledge.

Bannister, J., Fyfe, N., \& Kearns, A. (2006). Respectable or respectful? (In) civility and the city. Urban Studies, 43(5-6), 919-937.

Bannister, J., \& Kearns, A. (2013). The function and foundations of urban tolerance: Encountering and engaging with difference in the city. Urban Studies, 50(13), 2700-2717.

Bass, S. (2001). Policing space, policing race: Social control imperatives and police discretionary decisions. Social Justice, 28(1), 156-177.

Benz, T. A. (2014). At the intersection of urban sociology and criminology: Fear of crime and the postindustrial city. Sociology Compass, 8(1), 10-19.

Bottoms, A. (1995). The philosophy and politics of punishment and sentencing. In C. Clarkson \& R. Morgan (Eds.), The Politics of Sentencing Reform (pp. 17-49). Oxford: Clarendon Press.

Campbell, Christopher M. (2015). Popular punitivism: Finding a balance between the politics, presentation, and fear of crime. Sociology Compass, 9(3), 180-195.

Camps, V., \& Giner, S. (1998). Manual de Civisme. Barcelona: Arial.

Cardús, S. (2003). Ben Educats: Una defensa útil de les convencions, el civisme i l'autoritat. Barcelona: La Campana.

Cardús, S. (2006). L'educació del civisme. De la retòrica dels valors a la bona organització. Diàlegs Interiors, 1, 79-122.

Cohen, S. (2002). Folk devils and moral panics: The creation of the mods and rockers (3rd ed.). London: Routledge.

Comissió de Presidència, Hisenda i Equilibri Territorial. (2005). Projecte d'ordenança de Mesures per Fomentar i Garantir La Convivència Ciutadana a La Ciutat de Barcelona. Retrieved May 4, 2015, from http://www.bcn.cat/conselldeciutat/pdf/plenari_22novembre_projecte_ordenanca.pdf.

Curtis, R., \& Cuny, J. J. (2012). Report from the field: zero tolerance/stop and frisk policing in New York City. Dialectical Anthropology, 36(3-4), 343-352. https://doi.org/10.1007/s10624-012-9281-y.

De Giorgi, A. (2000). Zero tolleranza: Strategie e pratiche della società di controllo. Roma: DeriveApprodi.

Debray, R. (2000). El Civisme Explicat a La Meva Filla. Barcelona: Empúres.

Di Ronco, A. (2017). Understanding uncivil behaviour through urban space and culture. In N. Peršak (Ed.), Regulation and social control of incivilities. Routledge studies in crime and society (pp. 122-138). Abingdon, Oxon, UK, and New York: Routledge.

Diari de Girona. (2012). 'Passadissos nets i segurs' a Salt, Diari de Girona. 6 February. Retrieved September 29, 2020, from https://www.diaridegirona.cat/comarques/2012/02/06/passadissos-nets-segur s-salt/545833.html.

Duneier, M. (1999). Sidewalk. New York: Farrar, Straus and Giroux.

Escur, N. (2003). Entrevista a Salvador Cardús, Sociólogo: "Un Incívico es un desequilibrado docial, por buena persona que sea." La Vanguardia, November 16, p. 6. Retrieved September 30, 2020, from http://hemeroteca.lavanguardia.com/preview/2003/11/16/pagina-6/34074331/pdf.html.

Fernández Bessa, C., \& Di Masso, A. (2018). Diez años de civismo "a golpe de ordenanza”: estudio sobre la aplicación de la ordenanza de convivencia en el espacio público de Barcelona. Barcelona Societat, 22, 27-50.

Fernández González, M. (2010). La Construcció del "Incívic" com a "Problema Social”. El paper de les imatges periodístiques en la legitimació de polítiques municipals autoritaries. Observatori del sistema Penal $i$ els DDHH-Universitat de Barcelona (pp. 1-27). Retrieved September 29, 2020, from https ://es.scribd.com/document/328750834/Analisi-Aparicio-i-Establiment-Incivic-La-Vanguardia-20032009-NOPUBLICAT-OSPDH. 
Fernández González, M. (2014). Matar al Chino: Entre la revolución urbanística y el asedio urbano en el barrio del Raval de Barcelona. Barcelona: Virus Editorial.

Fernández González, M. (2016). Viejos problemas y nuevos vecinos. Consecuencias de una gran reforma urbana en el barrio del Raval, Barcelona. AIBR Revista de Antropologia Iberoamericana, 11(2), 225-245. https://doi.org/10.11156/aibr.110204.

Galdon-Clavell, G. (2016). Uncivil cities: Insecurity, policy transfer, tolerance and the case of Barcelona's “Civility Ordinance". Urban Studies, 53(9), 1-17. https://doi.org/10.1177/0042098015581771.

Garcia, S., \& Ávila, D. (2016). La prevención securitaria como modo de gobierno: el caso de Madrid. Athenea Digital, 16(1), 43-82. https://doi.org/10.5565/rev/athenea.1729.

Giroux, H. (2003). Zero tolerance, domestic militarization, and the war against youth. Social Justice, $30(2), 59-65$.

Goffman, E. (1990). The presentation of self in everyday life. London: Penguin, 1990, cop. 1959.

Greene, J. R. (2014). Zero tolerance and policing. In M. D. Reisig \& R. J. Kane (Eds.), The Oxford handbook of police and policing (pp. 1-30). Oxford: Oxford University Press.

Guillen, F. (2009). De les finestres trencades a la lluita contra la delinqüència: alguns esglaons perduts. Apunts de Seguretat, 4(July), 7-28.

Haider, A. (2018). Mistaken identity: Race and class in the age of Trump. New York: Verso Books.

Hall, S. (1979). The great moving right show. Marxism Today (January): 14-20.

Hill, M. (2005). The public policy process. Essex, UK: Pearson Ed. Ltd.

Howell, K. Babe. (2016). The costs of "Broken Windows" policing: Twenty years and counting. Cardozo Law Review, 37(3), 1059-1073.

Ilan, J. (2011). Reclaiming respectability? The class-cultural dynamics of crime, community and governance in inner-city Dublin. Urban Studies, 48(6), 1137-1155.

Ismaili, K. (2006). Contextualizing the criminal justice policy-making process. Criminal Justice Policy Review, 17(3), 255-269. https://doi.org/10.1177/0887403405281559.

Johnson, B. D., Golub, A., \& McCabe, J. (2010). The international implications of quality-of-life policing as practiced in New York City. Police Practice and Research, 11(1), 17-29. https://doi. org/10.1080/15614260802)586368.

Kefalas, M. (2003). Working-class heroes: Protecting home, community, and nation in a Chicago Neighborhood. Berkeley, CA, and Los Angeles, CA: University of California Press.

Lefebvre, H. (1991). The production of space. Oxford: Basil Blackwell Ltd.

Lum, C. (2009). Community policing or zero tolerance? Preferences of police officers from 22 countries in transition. The British Journal of Criminology, 49(6), 788-809.

Lundsteen, M. (2015). Conflicts and convivencia. An ethnography of the social effects of "The Crisis" in a Small Catalan Town. PhD Thesis, Department of Social Anthropology, Faculty of Geography and History, University of Barcelona.

Lundsteen, M. (2018). 'El moro'-Discovering the hidden coloniality of the contemporary Spanish/ Catalan society and its colonial subjects. In L. Jensen, J. S. Krabbe, C. Groess-Green, \& Z. L. Pecic (Eds.), Postcolonial Europe: Comparative reflections after the Empires (pp. 197-219). New York: Rowman \& Littlefield.

Lundsteen, M. (2020). An iron fist in a velvet glove. Towards a new governance of the migrant other in Catalonia? Dialectical Anthropology, 44(1), 1-17. https://doi.org/10.1007/s10624-019-09579-w.

Merrifield, A. (2000). The dialectics of dystopia: disorder and zero tolerance in the city. International Journal of Urban and Regional Research, 24(2), 473-489.

Millie, A. (Ed.). (2009). Securing respect: Behavioural expectations and anti-social behaviour in the $U K$. Bristol, UK: Policy Press.

Mooney, J., \& Young, J. (2016). The decline in crime and the rise of anti-social behaviour. Probation Journal, 53(4), 397-407.

Muñoz, O. (2005). El que la hace no la paga, La Vanguardia, August 27. Retrieved September 29, 2020, from http://hemeroteca.lavanguardia.com/preview/2005/08/27/pagina-2/41208430/pdf.html.

OSPDH, Observatori del sistema penal i els DDHH. (2009). Informe d'investigació. Construcció Del Civisme i Gestió de La Convivència a l'espai Públic de La Ciutat de Barcelona. Fundació Bofill. Barcelona. Retrieved September 29, 2020, from https://docplayer.es/7898509-Construccio-del-civis me-i-gestio-de-la-convivencia-a-l-espai-public-de-la-ciutat-de-barcelona.html.

Onishi, N. (1994). Police announce crackdown on quality-of-life offenses. New York Times. March 13. Retrieved September 29, 2020, from https://www.nytimes.com/1994/03/13/nyregion/police-annou nce-crackdown-on-quality-of-life-offenses.html.

Oriola Folch, J. (Director) (2007). Barcelona 2006: L'any del Civisme: La Polèmica al voltant de La Llei Municipal de Convivència. Retrieved September 30, 2020, from https://www.youtube.com/watch ?v=jjL_91k8wGM. 
Putnam, R. D. (2000). Bowling alone: The collapse and revival of American community. New York: Simon and Schuster.

Roca i Junyent, M. (2003). Incivismo. La Vanguardia, September 16, p. 23. Retrieved September 29, 2020, from http://hemeroteca.lavanguardia.com/preview/2003/09/16/pagina-23/34009877/pdf.html.

Ruíz Simón, J. M. (2005). La ordenanza. La Vanguardia, December 29, p. 35. Retrieved September 29, 2020, from http://hemeroteca.lavanguardia.com/preview/2005/12/29/pagina-35/44791065/pdf.html.

Sassen, S. (1991). The global city: New York, London, Tokyo. Princeton, NJ: Princeton University Press.

Schütz, A. (1953). Common-sense and scientific interpretation of human action. Philosophy and Phenomenological Research, 14(1), 1-38. https://doi.org/10.2307/2104013.

Smith, N. (1996). The new urban Frontier: Gentrification and the revanchist city. New York: Routledge.

Smith, N. (2001). Global social cleansing: Postliberal revanchism and the export of zero tolerance. Social Justice, 28(3), 68-74.

Stuart, F. (2015). On the streets, under arrest: Policing homelessness in the 21st century. Sociology Compass, 9(11), 940-950. https://doi.org/10.1111/soc4.12324.

Subirats, M., Castells, M., Borja, J., Subirats, J., \& González, I. (Eds.). (2006). Civisme per La Convivència: Un Debat Obert. Barcelona: Icaria.

Taguieff, P.-A. (1988). La Force du préjugé. Essai sur le racisme et ses doubles. Paris: La Découverte.

TV3. (2010). Marxar del Raval. Retrieved September 17, 2018, from http://www.tv3.cat/videos/31003)15/ Marxar-del-Raval-1.

Wacquant, L. (2009). Prisons of poverty. Minneapolis, MN: University of Minnesota Press.

Wacquant, L., Slater, T., \& Borges Pereira, V. (2014). Territorial stigmatization in action. Environment and Planning A, 46(6), 1270-1280.

Wilson, J. Q. \& Kelling. G. (1982). Broken windows. The Atlantic Monthly, 249(March), 29-38.

Zuloaga, L. (2014). El espejismo de la seguridad ciudadana. Claves de su presencia en la agenda política. Madrid: Catarata.

Publisher's Note Springer Nature remains neutral with regard to jurisdictional claims in published maps and institutional affiliations. 